\title{
Pengembangan Jenjang Karir sebagai Strategi Mengelola Ketidakpuasan Kerja Perawat di Rumah Sakit
}

\author{
Career Development as a Strategy to Manage Nurse's Job Dissatisfaction at Hospital \\ Indra Wahju H, Nanditya Ika F, Hartojo \\ Program Studi Magister Manajemen Rumah Sakit Fakultas Kedokteran Universitas Brawijaya Malang
}

\begin{abstract}
ABSTRAK
Kepuasan kerja perawat yang kurang dan angka turnover perawat yang tinggi di RS tempat studi merupakan suatu masalah yang memerlukan perhatian dari manajemen Sumber Daya Manusia (SDM) agar tidak menjadi penyebab rendahnya mutu pelayanan kesehatan. Tujuan dari penelitian ini adalah untuk mengidentifikasi, menganalisa dan menentukan solusi dari faktor-faktor yang mempengaruhi kepuasan kerja perawat di RS ini. Penelitian ini menggunakan pendekatan deskriptif dengan cara survei menggunakan kuesioner, wawancara, dan diskusi. Analisis terhadap faktor yang paling mempengaruhi kepuasan kerja perawat di RS ini dilakukan melalui diskusi dengan anggota lima belas orang yang terdiri dari kepala ruangan dan kepala bagian keperawatan. Hasil diskusi menunjukkan bahwa faktor yang paling berpengaruh terhadap kepuasan kerja perawat adalah belum adanya program pengembangan karir di RS ini. Solusi untuk meningkatkan kepuasan kerja perawat di RS ini adalah merancang program pengembangan karier dengan membuat tool pengembangan jenjang karir perawat berdasarkan kompetensinya.
\end{abstract}

Kata Kunci: Jenjang karir, kepuasan kerja perawat

\section{ABSTRACT}

Nurse's low job satisfaction and high nurse's turnover at this hospital is an issue that requires the attention of Human Resources Management (HRM) in order to avoid low quality health services. The purpose of this study is to identify, analyze, and determine the solution of factors that affect nurse's job satisfaction at hospital. This study used a descriptive approach by surveying using questionnaires, interviews, and discussions. Analysis of the most affecting factors on nurse's job satisfaction at hospital was done through discussions with fifteen people including room manager and head of nursing. The discussion results show that the most influential factor on nurse's job satisfaction is no career development program in hospital. The solution to improve nurse's job satisfaction at hospital is by designing a career development program to create career development tool based on nurse's competence.

Keywords: Careerpath, nurse's job satisfaction

Korespondensi: Indra Wahju H. Program Studi Magister Manajemen Rumah Sakit Fakultas Kedokteran Universitas Brawijaya Malang, Jl.Veteran Malang Jawa Timur Tel. (0341)568989Email: iwhardjanti@gmail.com 


\section{PENDAHULUAN}

Pelayanan kesehatan rumah sakit yang berkualitas dipengaruhi oleh kepuasan kerja dan kinerja penyedia layanan, termasuk perawat. Sebagai tenaga kesehatan yang jumlahnya sekitar $40-60 \%$ jumlah tenaga kesehatan di rumah sakit, perawat mempunyai peranan penting dalam upaya meningkatkan pelayanan kesehatan. Pelayanan kesehatan yang berkualitas bagi pasien bergantung pada peran perawat dalam memberikan perawatan. Dengan demikian, pengelolaan sumber daya manusia (SDM) perawat di rumah sakit perlu dilakukan untuk meningkatkan kepuasan kerja, sehingga meningkatkan kinerja perawat dan mutu pelayanan kesehatan $(1,2)$.

Berdasarkan data SDM RS tempat studi persentase turnover perawat di RS X adalah $13 \%$ dan angka ini lebih tinggi dibandingkan standar turnover menurut Leap dalam Lusiati dan Supriyanto yaitu 10-11\% per tahun (3) dan menurut Gillis dalam Mardiana et al, standar turnover $5-10 \%$ per tahun (4). Data kepuasan kerja perawat rawat inap RS X tentang kesesuaian pekerjaan, kerja tim, dan lingkungan kerja menunjukkan angka yang sangat tinggi, yaitu $90,62 \%$. Kepuasan kerja perawat tentang fasilitas yang diterima mempunyai nilai paling rendah, yaitu 43,75\%. Kepuasan kerja terhadap gaji, kesempatan pengembangan karir, kesempatan peningkatan kompetensi dengan pendidikan dan pelatihan adalah $62,5 \%$, dan kepuasan tentang komunikasi sebesar $65 \%$ (data primer).

Masih adanya aspek kepuasan kerja yang lemah perlu dikaji karena kepuasan kerja yang kurang akan berdampak kepada kinerja perawat dan dapat menjadi salah satu penyebab peningkatan intensi turnover perawat. Kepuasan kerja sering dijadikan ukuran adanya masalah mendasar sehingga organisasi perlu melakukan upaya untuk mengatasinya (5). Beberapa penelitian telah membuktikan bahwa kepuasan kerja perawat berdampak kepada kinerja perawat. Kinerja perawat tersebut dapat mempengaruhi kualitas pelayanan sehingga berdampak pada turnover perawat $(3,6)$.

Tujuan dari penelitian ini adalah untuk mengidentifikasi dan menganalisa faktor-faktor yang mempengaruhi kepuasan kerja perawat RS di Malang, memberikan alternatif solusi dan memberikan rekomendasi atas permasalahan kepuasan kerja perawat RS di Malang. Penelitian ini diharapkan dapat membantu RS di Malang dalam mengelola ketidakpuasan kerja sebagai dasar mengembangkan strategi manajemen SDM di RS tempat studi Malang untuk meningkatkan kinerja, mutu pelayanan, dan mengurangi intensi turnover perawat.

\section{METODE}

Penelitian ini dilakukan dengan pendekatan desktriptif. Penelitian ini dilakukan selama dua bulan dari tanggal 1

September 2015 sampai tanggal 31 Oktober 2015 di RS X Malang. Penelitian ini dilakukan dengan wawancara dan diskusi dengan kepala bagian SDM, kepala bagian keperawatan, dan ketua komite keperawatan secara terpisah di ruang rapat rumah sakit untuk mengetahui faktor-faktor yang menjadi penyebab ketidakpuasan dalam bekerja. Berdasarkan data kepuasan kerja yang dilakukan pada studi pendahuluan, diambil kepuasan kerja yang berada di bawah $90 \%$ (standar kepuasan kerja RS X Malang adalah $\geq 90 \%$ ). Kemudian dilakukan penentuan faktor yang paling berpengaruh terhadap ketidakpuasan kerja perawat dengan metode skoring berdasarkan USG (urgency, seriousness, growth) pada saat saat diskusi. Setiap masalah diberi skor berdasarkan USG dengan interval dari $1-5$, total skor tertinggi menjadi prioritas masalah ketidakpuasan kerja perawat di RSX.

Kemudian dilakukan diskusi yang melibatkan empat belas orang kepala ruangan dan seorang kepala keperawatan untuk menentukan faktor yang paling berpengaruh terhadap kepuasan kerja perawat dilanjutkan dengan analisis "5 Why" dan brainstorming untuk menemukan akar permasalahan. Pemilihan alternatif solusi ditetapkan melalui diskusi dengan kepala keperawatan dan kepala ruangan, serta studi literatur untuk mendukung perencanaan penerapan solusi. Penentuan prioritas solusi menggunakan metode CARL (Capability, Accessibility, Readiness, Leverage) menggunakan skor 0-4, sehingga solusi yang terpilih diharapkan dapat diaplikasikan dan sesuai dengan kebutuhan rumah sakit. C=Capability (ketersediaan sumber daya misalnya dana, sarana, dan peralatan); $A=$ Accessibility (kemudahan, masalah yang ada mudah diatasi atau tidak, kemudahan dapat didasarkan pada ketersediaan metode/cara/teknologi serta penunjang pelaksana seperti peraturan); $\mathrm{R}=$ Readiness (kesiapan dari tenaga pelaksana maupun kesiapan sasaran, seperti keahlian atau kemampuan motivasi); dan $\mathrm{L}=$ Leverage (seberapa besar pengaruh kriteria yang satu dengan yang lain dalam pemecahan masalah yang dibahas).

\section{HASIL}

Wawancara dan diskusi dengan kepala bagian SDM menghasilkan kesimpulan bahwa kepuasan kerja yang rendah disebabkan karena faktor motivasi kerja perawat yang kurang. Motivasi kerja yang kurang disebabkan kurangnya pengakuan, minat pada pekerjaan, tanggung jawab, serta kemajuan dan prestasi. Hasil wawancara dengan ketua komite keperawatan diperoleh kesimpulan bahwa kebutuhan untuk pengembangan jenjang karir diperlukan di RS, tetapi bagian SDM kesulitan karena RS tidak memiliki tool untuk penilaian kinerja untuk perawat. Hasil wawancara dengan kepala keperawatan didapatkan bahwa gaji bukanlah merupakan hal yang paling mendasar yang menyebabkan ketidakpuasan kerja di RS, karena masih ada insentif jasa pelayanan yang diterima selain gaji. Rumah sakit belum mempunyai aturan pengembangan sistem jenjang karir dan pengembangan potensi melalui pendidikan.

Tabel 1 menunjukkan bahwa kesempatan pengembangan karir menjadi prioritas masalah ketidakpuasan kerja

Tabel 1. Pembobotan dengan metode USG

\begin{tabular}{cllllcc}
\hline No & Masalah & U & S & G & Total skor & Rata-rata pembobotan \\
\hline 1 & Gaji dan kompensasi & 3 & 3 & 3 & 9 & 3 \\
2 & Fasilitas yang diterima & 3 & 3 & 3 & 9 & 10 \\
3 & Kejelasan prosedur & 3 & 4 & 3 & 3,3 \\
\hline
\end{tabular}


Tabel 1. Pembobotan dengan metode USG (lanjutan)

\begin{tabular}{|c|c|c|c|c|c|c|}
\hline No & Masalah & $\mathbf{U}$ & $\mathbf{S}$ & $\mathbf{G}$ & Total skor & Rata-rata pembobotan \\
\hline 4 & Kesempatan pengembangan karir & 4 & 4 & 5 & 13 & 4,3 \\
\hline 5 & $\begin{array}{l}\text { Kesempatan peningkatan kompetensi dengan } \\
\text { pelatihan dan pendidikan }\end{array}$ & 3 & 4 & 4 & 11 & 3,7 \\
\hline 6 & Potensi diri & 3 & 4 & 4 & 11 & 3,7 \\
\hline 7 & Komunikasi dengan atasan & 4 & 3 & 3 & 10 & 3,3 \\
\hline
\end{tabular}

Keterangan: berdasarkan skala likert 1-5 (5=sangat besar, 4=besar, 3=sedang, 2=kecil, 1=sangat kecil)

perawat dengan total skor paling tinggi yaitu 13 . menjadiprioritas masalah.

Permasalahan ketidakpuasan lain yang juga dianggap penting adalah peningkatan kompetensi dan potensi diri, diikuti kejelasan prosedur dan komunikasi dengan atasan.

Menarik untuk dikaji bahwa faktor gaji dan fasilitas bukan

Tabel 2 menunjukkan bahwa akar permasalahan pengembangan jenjang karir adalah belum adanya regulasi (kebijakan dan pedoman) tentang sistem pengembangan jenjang karir dan kurangnya dukungan

Tabel 2. Rumusan akar masalah dengan pertanyaan " 5 Why"

\begin{tabular}{|c|c|c|c|c|c|c|c|}
\hline No. & Faktor & Rumusan Masalah & Why I & Why II & Why III & Why IV & Why V \\
\hline \multirow[t]{3}{*}{1.} & Manpower & Perawat belum & Tidak ada & Belum ada & Jenjang karir & Belum ada & Belum ada \\
\hline & & punya tujuan karir & $\begin{array}{l}\text { kepastian jenjang } \\
\text { karir }\end{array}$ & $\begin{array}{l}\text { tool jenjang } \\
\text { karir }\end{array}$ & belum dibuat & $\begin{array}{l}\text { Perencanaan } \\
\text { pengembangan } \\
\text { jenjang karir }\end{array}$ & $\begin{array}{l}\text { kebijakan } \\
\text { pengembangan } \\
\text { jenjang karir }\end{array}$ \\
\hline & & $\begin{array}{l}\text { Belum ada yang } \\
\text { mengerti tentang } \\
\text { pembuatan Jenjang } \\
\text { karir }\end{array}$ & $\begin{array}{l}\text { Belum tahu } \\
\text { manfaat } \\
\text { jenjang karir }\end{array}$ & $\begin{array}{l}\text { Belum ada } \\
\text { sosialisasi } \\
\text { jenjang karir }\end{array}$ & $\begin{array}{l}\text { Jenjang karir } \\
\text { belum dibuat }\end{array}$ & $\begin{array}{l}\text { Belum ada } \\
\text { perencanaan } \\
\text { pengembangan } \\
\text { jenjang karir }\end{array}$ & $\begin{array}{l}\text { Belum ada } \\
\text { kebijakan } \\
\text { pengembangan } \\
\text { jenjang karir }\end{array}$ \\
\hline \multirow[t]{2}{*}{2.} & Method & $\begin{array}{l}\text { Pedoman/Standar } \\
\text { Prosedur Operasional } \\
\text { yang berkaitan } \\
\text { dengan sistem } \\
\text { pengembangan } \\
\text { jenjang karir belum } \\
\text { ada }\end{array}$ & Belum dibuat & $\begin{array}{l}\text { Belum ada } \\
\text { perintah } \\
\text { manajemen } \\
\text { untuk membuat }\end{array}$ & $\begin{array}{l}\text { Belum ada } \\
\text { kebijakan tentang } \\
\text { jenjang karir }\end{array}$ & $\begin{array}{l}\text { Belum dirasa perlu } \\
\text { karena bukan } \\
\text { prioritas }\end{array}$ & $\begin{array}{l}\text { Kurang dukungan } \\
\text { manajemen }\end{array}$ \\
\hline & & $\begin{array}{l}\text { Belum ada } \\
\text { kebijakan tentang } \\
\text { jenjang karir bagi } \\
\text { perawat }\end{array}$ & Belum dibuat & $\begin{array}{l}\text { Dianggap belum } \\
\text { menjadi hal yang } \\
\text { penting }\end{array}$ & $\begin{array}{l}\text { Manajemen } \\
\text { Belum } \\
\text { Menjadikan } \\
\text { Jenjang karir } \\
\text { sebagai prioritas }\end{array}$ & $\begin{array}{l}\text { Ada prioritas lain } \\
\text { yang lebih penting }\end{array}$ & $\begin{array}{l}\text { Kurangnya } \\
\text { dukungan } \\
\text { manajemen }\end{array}$ \\
\hline 3. & Machine & $\begin{array}{l}\text { Penilaian kinerja } \\
\text { Perawat belum } \\
\text { terstruktur }\end{array}$ & $\begin{array}{l}\text { Tool evaluasi } \\
\text { kinerja belum ada }\end{array}$ & $\begin{array}{l}\text { Tool belum } \\
\text { dibuat }\end{array}$ & $\begin{array}{l}\text { Belum ada } \\
\text { pedoman dan } \\
\text { SPO }\end{array}$ & $\begin{array}{l}\text { Belum ada kebijakan } \\
\text { kebijakan tentang } \\
\text { evaluasi }\end{array}$ & $\begin{array}{l}\text { Kurangnya } \\
\text { dukungan } \\
\text { manajemen }\end{array}$ \\
\hline \multirow[t]{5}{*}{4.} & Material & $\begin{array}{l}\text { Pelatihan yang } \\
\text { konsisten untuk } \\
\text { mendukung } \\
\text { kompetensi belum } \\
\text { terstruktur }\end{array}$ & $\begin{array}{l}\text { Belum ada } \\
\text { perencanaan } \\
\text { pelatihan yang } \\
\text { terstruktur }\end{array}$ & $\begin{array}{l}\text { Dukungan } \\
\text { manajemen } \\
\text { kurang }\end{array}$ & $\begin{array}{l}\text { Belum dianggap } \\
\text { perlu }\end{array}$ & $\begin{array}{l}\text { Belum merupakan } \\
\text { prioritas }\end{array}$ & $\begin{array}{l}\text { Belum ada } \\
\text { kebijakan }\end{array}$ \\
\hline & & $\begin{array}{l}\text { Uraian tugas } \\
\text { antar perawat } \\
\text { masih sama }\end{array}$ & $\begin{array}{l}\text { Alur layanan } \\
\text { pembagian tugas } \\
\text { belum tertata }\end{array}$ & Belum dibuat & $\begin{array}{l}\text { Penentuan } \\
\text { kompetensi } \\
\text { belum dilakukan }\end{array}$ & $\begin{array}{l}\text { Belum ada SPO } \\
\text { penentuan } \\
\text { kompetensi }\end{array}$ & $\begin{array}{l}\text { Belum ada } \\
\text { kebijakan }\end{array}$ \\
\hline & & $\begin{array}{l}\text { Rapot karyawan } \\
\text { belum tertata }\end{array}$ & $\begin{array}{l}\text { Evaluasi kinerja } \\
\text { belum ada }\end{array}$ & $\begin{array}{l}\text { Belum ada tool } \\
\text { penilaian }\end{array}$ & Belum dibuat & $\begin{array}{l}\text { Belum ada SPO } \\
\text { tentang evaluasi }\end{array}$ & $\begin{array}{l}\text { Belum ada } \\
\text { kebijakan }\end{array}$ \\
\hline & & & & & & kinerja & \\
\hline & & $\begin{array}{l}\text { Pengembangan } \\
\text { jenjang karir } \\
\text { belum ada }\end{array}$ & $\begin{array}{l}\text { Belum ada } \\
\text { rapot karyawan }\end{array}$ & $\begin{array}{l}\text { Belum ada } \\
\text { penilaian kinerja }\end{array}$ & $\begin{array}{l}\text { Belum ada tool } \\
\text { penilaian }\end{array}$ & Belum dibuat & $\begin{array}{l}\text { Belum ada } \\
\text { regulasi tentang } \\
\text { jenjang karir }\end{array}$ \\
\hline 5. & Money & $\begin{array}{l}\text { Alokasi dana untuk } \\
\text { Diklat belum jelas }\end{array}$ & $\begin{array}{l}\text { Belum merupakan } \\
\text { prioritas }\end{array}$ & $\begin{array}{l}\text { Ada program lain } \\
\text { yang lebih } \\
\text { penting }\end{array}$ & $\begin{array}{l}\text { Dukungan } \\
\text { manajemen } \\
\text { kurang }\end{array}$ & & \\
\hline
\end{tabular}


manajemen terhadap pengembangan jenjang karir di RS ini.

Tahap selanjutnya dilakukan pemilihan alternatif solusi berdasarkan akar masalah yang mempunyai kontribusi dan daya ungkit terbesar untuk menyelesaikan masalah. Hasil pemilihan solusi dengan metode CARL (Tabel 4) menunjukkan bahwa skor tertinggi pembuatan tool pengembangan jenjang karir dengan total skor 60, sehingga pembuatan tool pengembangan jenjang karir disepakati sebagai solusi terhadap belum adanya sistem pengembangan jenjang karir perawat di RSX dalam rangka meningkatkan kepuasan kerja perawat. Pemilihan alternatif solusi pembuatan tool pengembangan jenjang karir perawat berdasarkan pertimbangan saat diskusi bahwa solusi tersebut memiliki daya ungkit lebih besar dibanding alternatif solusi lainnya dan kemampuan rumah sakit untuk melaksanakan pengembangan jenjang karir.

\section{DISKUSI}

\section{Gambaran Umum Kepuasan Kerja Perawat di RS}

Data kepuasan kerja perawat dan hasil wawancara di RS tempat studi menunjukkan bahwa pada dasarnya sudah banyak perawat yang merasa puas, terutama aspek kesesuaian pekerjaan, kerja tim dan lingkungan pekerjaan. Disisi lain pada aspek seperti fasilitas yang diperoleh, gaji dan kompensasi, kesempatan pengembangan karir, kesempatan peningkatan kompetensi melalui pendidikan dan pelatihan cenderung menyebabkan perawat tidak puas. Kepuasan kerja dipengaruhi banyak faktor sehingga kepuasan kerja dapat mewakili kepuasan kerja secara umum maupun mengacu kepada bagian pekerjaan tertentu. Secara umum seseorang dapat memiliki tingkat kepuasan yang sangat tinggi pada aspek kepuasan kerja tertentu, tetapi orang tersebut dapat merasa tidak puas dengan salah satu atau beberapa faktor yang mempengaruhi kepuasan kerja yang lain (7).

Terdapat dua faktor yang mempengaruhi kepuasan kerja menurut two-factor theory dari Herzberg, yang menggunakan teori Abraham Maslow sebagai titik acuan, yaitu faktor intrinsik dan ekstrinsik. Kepuasan kerja ditentukan oleh faktor-faktor yang menyebabkan satisfaction (kepuasan) dan dissatisfaction (ketidakpuasan). Pada teori ini, ketidakpuasan dihubungkan dengan kondisi di sekitar pekerjaan (seperti kondisi kerja, pengupahan, keamanan, kualitas pengawasan, dan hubungan dengan orang lain), dan bukan dengan pekerjaan itu sendiri. Karena faktor ini mencegah reaksi negatif, dinamakan sebagai hygiene atau maintenance factors atau disebut juga faktor ekstrinsik. Sebaliknya, kepuasan dilihat dari faktor yang terkait dengan pekerjaan itu sendiri atau hasil langsung dari pekerjaan, seperti sifat pekerjaan, prestasi dalam

pekerjaan, peluang promosi dan kesempatan untuk pengembangan diri dan pengakuan. Karena faktor ini berkaitan dengan tingkat kepuasan kerja tinggi, dinamakan motivators atau disebut juga faktor intrinsik $(8,9)$. Faktor ekstrinsik hanya memastikan karyawan tidak merasakan ketidakpuasan atau berada pada titik nol landasan motivasi. Untuk membuat karyawan merasakan kepuasan kerja yang tinggi, maka pimpinan harus menyediakan faktor motivator (intrinsik) kepada karyawan seperti prestasi, pengakuan, tanggung jawab dan pengembangan kesempatan untuk maju (8).

Kunci kepuasan bukanlah jumlah uang yang dibayarkan melainkan persepsi keadilan. Individu yang mempersepsikan keputusan promosi dibuat dengan cara yang adil, kemungkinan besar karyawan tersebut mengalami kepuasan dalam pekerjaan $(10,11)$. Pada aspek kesempatan berkembang, perawat akan merasa puas bekerja karena menyadari apa yang dicapainya merupakan suatu yang maksimal dengan upaya yang optimal. Di RS X kesempatan untuk berkembang meningkatkan potensi diri dalam meningkatkan pengetahuan, ketrampilan, dan keahlian masih belum tertata sehingga menimbulkan kepuasan kerja yang kurang bagi individu, sedangkan bagi rumah sakit keuntungan yang diharapkan adalah terjaminnya kualitas sumber daya manusia yang dimiliki serta pemanfaatannya secara optimal untuk mewujudkan tujuan organisasi rumah sakit (12). Menurut teori Maslow, kebutuhan dasar manusia yang paling tinggi adalah kesempatan seseorang untuk mengembangkan potensi yang dimiliki (11). Kesempatan diri mengembangkan potensinya dapat diakomodir secara sistematis dalam sistem jenjang karir. Kategori 'fasilitas yang diterima' merupakan yang terendah $(43,75 \%)$. Kriteria tersebut menimbulkan persepsi yang berbeda, karena pertanyaan yang diajukan kurang bisa menjelaskan maksud yang terkandung dari3 ditemukan sebagai akar masalah ketidakpuasan kerja pada perawat. Pengembangan atau kesempatan promosi tenaga keperawatan di RS X belum tertata dengan baik antara lain belum adanya prosedur seleksi bagi karyawan yang akan melanjutkan pendidikan maupun penempatan bagi yang sudah melaksananakan pendidikan, sistem penjenjangan karier yang jelas, mekanisme penunjukkan tenaga yang mengikuti pelatihan, acara sosialiasasi hasil pelatihan perawat. Selain itu, penentuan kompetensi perawat juga belum dilakukan sehingga uraian tugas antar perawat masih sama. Evaluasi kinerja di RS X belum ada dikarenakan tool evaluasi kinerja berdasarkan kompetensi belum dibuat dan tool pengembangan jenjang karir perawat berdasarkan kompetensi juga belum dibuat. Akar masalah tidak adanya

Tabel 3. Pemilihan alternatif solusi dengan metode CARL

\begin{tabular}{|c|c|c|c|c|c|c|}
\hline & Alternatif Solusi & $\begin{array}{c}\text { Capabillty } \\
(1-4)\end{array}$ & $\begin{array}{c}\text { Accessibility } \\
(1-4)\end{array}$ & $\begin{array}{c}\text { Readiness } \\
(1-4)\end{array}$ & $\begin{array}{c}\text { Leverage } \\
(1-4)\end{array}$ & $\begin{array}{c}\text { Jumlah } \\
\text { skor }\end{array}$ \\
\hline 1. & Pembuatan SK dan SPO oleh manajemen & 3 & 2 & 2 & 2 & 33 \\
\hline 2. & $\begin{array}{l}\text { Penganggaran alokasi dana pendidikan dan pelatihan } \\
\text { untuk meningkatkan kompetensi }\end{array}$ & 3 & 2 & 2 & 2 & 32 \\
\hline 3. & Penentuan kompetensi perawat & 3 & 3 & 3 & 2 & 40 \\
\hline 4 & Pembuatan tool penilaian kinerja berdasar kompetensi & 4 & 3 & 3 & 2 & 46 \\
\hline 5 & Pembuatan tool pengembangan jenjang karir perawat & 4 & 3 & 3 & 4 & 60 \\
\hline
\end{tabular}


pengembangan jenjang karir yang ditemukan saat diskusi adalah belum adanya regulasi rumah sakit tentang pengembangan sistem jenjang karir dan kurangnya dukungan manajemen dalam pengembangan jenjang karir.

Menurut Swanburg dalam Lelonowati et al, salah satu fungsi manajemen adalah memimpin sebagai proses pendelegasian, pengawasan, koordinasi dan pengendalian implementasi rencana organisasi. Fokusnya adalah membimbing dan meningkatkan motivasi dengan upaya yang dilakukan yaitu: 1) membuat sistem penghargaan; 2) memberikan umpan balik positif; 3) mengintegrasikan tujuan organisasi dengan staf/individu; 4) mengurangi ketidakpuasan kerja; 5) mendukung SDM, persediaan dan perlengkapan; 6) program diklat (13). Rumah Sakit ini belum memberikan dukungan yang maksimal terhadap program pengembangan jenjang karir perawat. Alternatif solusi yang diberikan antara lain, memberikan dukungan terhadap sumber daya manusia perawat berupa penganggaran dana untuk pendidikan pelatihan dalam meningkatkan kompetensi perawat diperjelas, penentuan kompetensi perawat, pembuatan tool evaluasi kinerja perawat berdasarkan kompetensinya, dan pembuatan tool pengembangan jenjang karir perawat. Alternatif pemecahan masalah yang disepakati adalah pembuatan tool pengembangan sistem jenjang karir perawat berdasarkan kompetensi.

Pengembangan sistem jenjang karir bagi perawat membedakan antara pekerjaan (job) dan karir (career). Pekerjaaan adalah suatu posisi yang diberikan/ditugaskan dan terikat hubungan antara atasan dan bawahan serta mendapatkan imbalan berupa uang. Karir mengarah pada keberhasilan pekerjaan (kinerja), diartikan sebagai suatu jenjang yang dipilih individu untuk dapat memenuhi kepuasan kerja perawat, sehingga pada akhirnya akan memberikan kontribusi terhadap bidang profesi yang dipilihnya. Karir merupakan investasi, bukan sekedar mendapatkan penghargaan atau imbalan jasa. Komitmen terhadap karir dapat dilihat dari sikap perawat terhadap profesinya dan motivasi untuk bekerja sesuai dengan karir yang telah dipilih $(14,15)$.

Pengembangan karir profesional perawat bertujuan meningkatkan moral kerja dan mengurangi kebuntuan karir (dead end job/career), menurunkan jumlah perawat

\section{DAFTAR PUSTAKA}

1. Suroso J. Penataan Sistem Jenjang Karir Berdasar Kompetensi untuk Meningkatkan Kepuasan Kerja dan Kinerja Perawat di Rumah Sakit. Eksplanasi. 2012; 6(2): 123-131.

2. Sirin M and Sokmen SM. Quality of Nursing Work Life Scale: The Psychometric Evaluation of the Turkish Version. International Journal of Caring Sciences. 2015; 8(3): 543-556.

3. Lusiati A dan Supriyanto S. Dampak Faktor Individu, Faktor Pekerjaan dan Faktor Organisasi pada Kepuasan Kerja dan Intensi Turnover Perawat. Jurnal Administrasi Kesehatan Indonesia. 2013; 1(2): 156166.

4. Mardiana I, Hubeis AVS, dan Panjaitan NK. Hubungan Kepuasan Kerja dengan Turnover Intentions pada Perawat Rumah Sakit Dhuafa. Jurnal Manajemen yang keluar dari pekerjaan (turnover), menata sistem promosi berdasarkan persyaratan dan kriteria yang telah ditetapkan sehingga mobilitas karir berfungsi dengan baik dan benar. Pengembangan sistem jenjang karir profesional perawat klinik atau perawat yang bertugas melakukan pelayanan kepada pasien di rumah sakit ditujukan terutama bagi perawat yang bekerja sebagai perawat pelaksana di sarana kesehatan dan dimulai dari perawat profesional pemula (16). Dalam pengembangan sistem jenjang karir perawat tersebut ada beberapa hal yang yang perlu dilakukan lebih dulu sebagai dasar dalam penentuan jenjang seorang perawat seperti masa kerja, kompetensi, pendidikan dan pelatihan yang dimiliki, serta hasil raport karyawan yang didapatkan dari hasil penilaian kinerja perawat.

Untuk mencapai sistem jenjang karir professional perawat maka sikap, pengetahuan dan ketrampilan perawat harus ditingkatkan sesuai dengan kompetensinya. Rumah sakit harus mengupayakan adanya pendidikan dan pelatihan berkesinambungan bagi perawat dan didukung dengan adanya penghargaan baik pengakuan atas hasil kerja, promosi jabatan maupun dalam bentuk finansial, untuk memotivasi perawat dan memberikan kepuasan kerja bagi perawat $(16,17)$. Pengembangan karir perawat merupakan harapan setiap perawat dan dapat meningkatkan kinerja dan kepuasan kerja. Oleh karena itu, RS ini diharapkan dapat melaksanakan pengembangan karir professional perawat berdasarkan kompetensi, pengetahuan dan ketrampilan untuk mencapai jenjang berikutnya dan diikuti dengan pemberian remunerasi sesuai dengan level dan katagori. Model pengembangan karir yang jelas juga akan mendorong setiap tenaga keperawatan untuk terus meningkat ke jenjang karir yang diinginkan (16).

Akar masalah kepuasan kerja perawat di RS ini adalah belum adanya regulasi RS ini dalam pengembangan sistem jenjang karir dan kurangnya dukungan manajemen dalam pengembangan jenjang karir. Alternatif solusi yang disepakati adalah pembuatan tool pengembangan jenjang karir berdasarkan kompetensi, sehingga penentuan kompetensi dan tool evaluasi kinerja dapat diakomodir. Jenjang karir profesional perawat diperlukan untuk terwujudnya pelayanan yang bemutu mengingat perawat merupakan tenaga terbanyak dan terlama mendampingi pasien.

Pengembangan Industri Kecil Menengah. 2014; 9(2): 119-130.

5. Mosadeghrad AM. Quality of Working Life: An Antecedent to Employee Turnover Intention. International Journal of Health Policy and Management. 2013; 1(1): 43-50.

6. Newman K, Maylor U, and Chansarkar B. "The Nurse Satisfaction, Service Quality and Nurse Retention Chain" Implications for Management of Recruitment and Retention. Journal of Management in Medicine. 2002; 16(4-5): 271-291.

7. Noras JU dan Sartika RAD. Perbandingan Tingkat Kepuasan Kerja Perawat dan Kepuasan Pasien. Jurnal Kesehatan Masyarakat Nasional. 2012; 6(5): 234-240.

8. Faramita NI, Mansur M, dan Huda S. Faktor-Faktor yang Mempengaruhi Kepuasan Kerja Tenaga Kesehatan di RS $X$ Kepanjen. Jurnal Kedokteran 
Brawijaya. 2014; 28(1): 47-53.

9. Wibowo. Manajemen Kerja. Edidi ke 4. Jakarta: PT. Raja Grafindo Perkasa; 2014.

10. Andini R. Analisis Pengaruh Kepuasan Gaji, Kepuasan Kerja, Komitmen Organisasional Terhadap Turnover Intention (Studi Kasus Pada Rumah Sakit Roemani Muhammadiyah Semarang). [Tesis]. Universitas Diponegoro, Semarang, 2006.

11. Sitinjak L. Pengaruh Penerapan Sistem Jenjang Karier terhadap Kepuasan Kerja Perawat di RS PGI Â Cikini. [Tesis]. Universitas Indonesia, Jakarta. 2008.

12. Brahmasari IA dan Suprayetno A. Pengaruh Motivasi Kerja, Kepemimpinan dan Budaya Organisasi terhadap Kepuasan Kerja Karyawan serta Dampaknya pada Kinerja Perusahaan (Studi kasus pada PT. Pei Hai International Wiratama Indonesia). Jurnal Manajemen dan Kewirausahaan (Journal of Management and Entrepreneurship). 2008; 10(2): 124-135.

13. Lelonowati D, Koeswo M, dan Rochmad K. Faktor Penyebab Kurangnya Kinerja Surveilans Infeksi
Nosokomial di RSUD Dr. Iskak Tulungagung. Jurnal Kedokteran Brawijaya. 2015; 28(2): 186-194.

14. Budiono S, Noermijati, dan Alamsyah A. Pengaruh Spiritualitas di Tempat Kerja terhadap Turnover Intention Perawat melalui Komitmen Organisasional di Rumah Sakit Islam Unisma Malang. Jurnal Aplikasi Manajemen. 2015; 12(4): 639-649.

15. Mosadeghrad AM, Ferlie E, and Rosenberg D. A Study of the Relationship between Job Satisfaction, Organizational Commitment and Turnover Intention among Hospital Employees. Health Services Management Research. 2008; 21(4): 211-227.

16. Kolibu FK, Hariyanto $T$, dan Pusparahaju A. Pengembangan Model Jenjang Karir Perawat Klinis di Unit Rawat Inap Rumah Sakit. Jurnal Kedokteran Brawijaya. 2014; 28(1): 59-64.

17. Kacel B, Miller M, and Norris D. Measurement of Nurse Practitioner Job Satisfaction in a Midwestern State. Journal of the American Academy of Nurse Practitioners. 2005; 17(1): 27-32. 